\title{
Small Supernumerary Marker Chromosomes (sSMC) in Patients with a 45,X/46,X,+mar Karyotype - 17 New Cases and a Review of the Literature
}

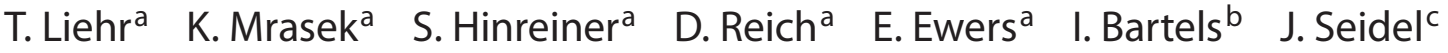

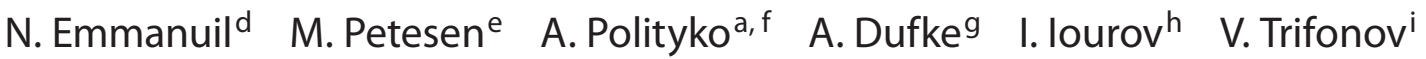 \\ J. Vermeesch ${ }^{j} \quad$ A. Weise ${ }^{a}$ \\ anstitut für Humangenetik und Anthropologie, Jena; bSRH Waldklinikum Gera, Gera; 'Institut für Humangenetik, \\ Zentrum für Hygiene und Humangenetik, Göttingen, Germany; ${ }^{d}$ Bioiatriki S.A., Athens; ${ }^{e}$ Genomedica, Pireas, \\ Greece; Institute of Hereditary Diseases, Minsk, Belarus; ${ }^{9}$ Institut für Humangenetik, Medizinische Genetik,

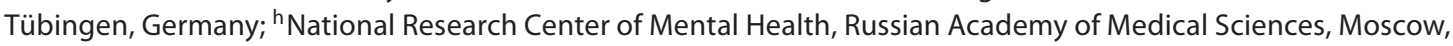

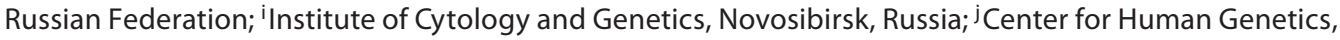 \\ University Hospital Leuven, Belgium
}

\section{Key Words}

Fluorescence in situ hybridization (FISH) •

Gonadoblastoma $\cdot$ Incidence $\cdot$ Small supernumerary

marker chromosome (sSMC) • Turner syndrome

\begin{abstract}
Small supernumerary marker chromosomes (sSMC) can appear in a numerically normal 'basic karyotype', but also in a numerically abnormal one like a Turner syndrome karyotype $\left(=\mathrm{sSMC} \mathrm{C}^{\mathrm{T}}\right)$. Here we present 17 new cases with such a mos $45, X / 46, X,+$ mar karyotype. Moreover we reviewed all 512 cytogenetically similar cases available from the literature and supply for the first time data on occurrence, shapes and subgroups of this rare cytogenetic entity. $\mathrm{SSMC}^{\top}$ are very rare in the common population $(1: 100,000)$ - however, they can be observed with a 45- and even 60-times higher frequency in infertile and (develop)mentally retarded patients, respectively. Even though $\mathrm{SSMC}^{\top}$ derive from one of the gonosomes in $>99 \%$ of the cases, there are also exceptional reports on
\end{abstract}

\section{KARGER}

Fax +4161306 1234

E-Mail karger@karger.ch

www.karger.com
(C) 2008 S. Karger AG, Basel

$1661-5425 / 07 / 0016-0353 \$ 23.50 / 0$

Accessible online at:

www.karger.com/sxd
${ }_{S S M C}^{\top}$ derived from one of the autosomes. The majority of $\mathrm{sSMC}^{\top}(\mathrm{X})$ form ring chromosomes, while most $\mathrm{sSMC}^{\top}(\mathrm{Y})$ are inverted duplicated/isodicentric chromosomes. Although $>500 \mathrm{sSMC}^{\top}$ are reported, a detailed characterization of the chromosomal breakpoints is only given for a minority. Thus, more cases with detailed (molecular) cytogenetic marker chromosome characterization are needed to provide information on formation and effects of an SSMC'.

Copyright $\odot 2008$ S. Karger AG, Basel

Small supernumerary marker chromosomes (sSMC) are defined as structurally abnormal chromosomes that cannot be identified or characterized unambiguously by conventional banding cytogenetics alone; they are generally equal in size or smaller than a chromosome 20 of the same metaphase spread. sSMC can be present (1) in a karyotype of 46 normal chromosomes, (2) in a numerically abnormal karyotype (like Turner or Down syndrome) or (3) in a structurally abnormal but balanced 
karyotype (e.g. Robertsonian translocation or ring chromosome formation) [Liehr et al., 2004].

Recently, we reviewed all reported sSMC present additionally in a normal 'basic karyotype' of 46 chromosomes [Liehr et al., 2006; Liehr, 2007]. We also determined sSMC frequencies in different clinical subgroups: $0.075 \%$ in prenatal diagnoses, $0.044 \%$ in consecutively studied postnatal cases, $0.125 \%$ in infertile and 0.288 in (develop)mentally retarded patients [Liehr and Weise, 2007]. However, in the literature no special attention was ever given to sSMC present in a Turner karyotype of mos $45, \mathrm{X} / 46, \mathrm{X},+$ mar. sSMC in a Turner karyotype are abbreviated in the following as $\mathrm{SSMC}^{\mathrm{T}}$.

There are reviews on clinical aspects of mos 45,X/ 46,X,+mar karyotypes leading to female [Mittwoch, 1992; Ramos, 2007] or male phenotypes [Egozcue et al., 2000]. The question whether the karyotype was mos 45,X/46,XX (/47,XXX) or mos 45,X/46,XY(/47,XXY) [Hsu, 1994; Ogata and Matsuo, 1995] was also addressed and variation of mosaicism in different tissues was analyzed [Park et al., 1999]. Furthermore, in a mos $45, X / 46, X, d e r(X)$ karyotype it is important to test for the ability of the $\operatorname{der}(\mathrm{X})$ to be inactivated, i.e. for the presence of the XIST gene [Sagi et al., 2007]. Contrary, when a mos $45, X / 46, X, \operatorname{der}(Y)$ or $45, \mathrm{X} / 46, \mathrm{XY}$ karyotype is characterized, it is important to counsel the patient concerning a possible gonadoblasto$\mathrm{ma}$ and a preventive removement of gonadal tissue [Bianco et al., 2006]. In this context, the necessity of applying molecular approaches for detection of cryptic 45, X/46, XY mosaicism is discussed [Medlej et al., 1992; Nagafuchi et al., 1992; Binder et al., 1995; Nishi et al., 2002; Semerci et al., 2007], as a direct relationship between percentage of cells exhibiting a 45,X karyotype and the patient's phenotype does not exist [Alvarez-Nava et al., 2003].

Here we report on 17 new cases with an $\mathrm{sSMC}^{\mathrm{T}}$. Moreover, we review similar cases and provide for the first time data on the frequency and subgroups of the rare cytogenetic entity 'cases with an $\mathrm{SSMC}^{\mathrm{T}}$ '.

\section{Materials and Methods}

Cytogenetics and Molecular Cytogenetics

Seventeen cases with an $\mathrm{sSMC}^{\mathrm{T}}$ (table 1) were studied by cytogenetics and molecular cytogenetics.

GTG-banding was done according to standard procedures. Fluorescence in situ hybridization (FISH) was performed using commercially available centromeric probes for chromosomes $\mathrm{X}$ and $\mathrm{Y}$ according to the manufacturer's instruction (Abbott/Vysis). When indicated LSI SRY, a subtelomeric probe for X/Ypter
(Abbott/Vysis), or probes adjacent to the XIST region, RP11372C14 and RP11-183A17, were applied. Moreover, subcentromere-specific multicolor FISH (subcenM-FISH), using probe sets for the $\mathrm{X}$ and the $\mathrm{Y}$ chromosome, was done as previously reported [Starke et al., 2003]. In some cases also the multicolor banding (MCB) probe set for the X chromosome was applied [Liehr et al., 2002].

\section{Data Mining in the Literature}

Frequency of $46, X,+$ mar Cases. Recently we determined the sSMC frequency (for karyotypes 47,+mar) in different prenatal and postnatal entities [Liehr and Weise, 2007]. Here we did the same for $\mathrm{sSMC}^{\mathrm{T}}$ (see tables 2-4). The same literature as previously described was used, however, references reporting only sSMC frequencies were excluded here. For details on references and way of data mining see Liehr and Weise [2007]. For comparison, the frequencies of the karyotype (mos) 45, $\mathrm{X}$ without presence of an $\mathrm{sSMC}^{\mathrm{T}}$ were also determined in the corresponding clinical subgroups.

sSMC Homepage [Liehr, 2007]. We recently collected all literature on sSMC and made it available on the sSMC homepage [Liehr, 2007]. For this paper we assembled all presently available 512 sSMC $^{\mathrm{T}}$ [(mos) 46,X,+mar - see sub page of Liehr, 2007: http:// www.med.uni-jena.de/fish/sSMC/sturner.htm]. According to the cytogenetic definition of an sSMC [Liehr et al., 2004] only marker chromosomes smaller in size than a chromosome 20 are included. Thus, larger structurally aberrant X chromosomes, like $\mathrm{i}(\mathrm{Xq}), \mathrm{i}(\mathrm{Xp})$, etc. are not considered here. On the other hand, due to the small size of the male gonosome, practically all derivatives of the Y chromosome were taken into account. Only derivatives reported as $\operatorname{del}(\mathrm{Y})$ or $\operatorname{del}(\mathrm{Yq})$ were excluded, as they are easily characterized as shortened $\mathrm{Y}$ chromosomes and not as unidentified markers. Accordingly, 371 cases with an sSMC(Y) in contrast to only 139 sSMC(X) were included in Liehr [2007] - the 17 new cases reported here are already incorporated in this dataset.

All aforementioned published cases with an $\mathrm{SSMC}^{\mathrm{T}}$ were analyzed in detail for the quality of their cytogenetic description, shape of the $\mathrm{SSMC}^{\mathrm{T}}$ and their clinical outcome.

\section{Results and Discussion}

\section{New Cases with sSMC ${ }^{T}$}

In 17 cases with a $46, \mathrm{X},+$ mar karyotype the origin, shape and genetic content of the $\mathrm{SSMC}^{\mathrm{T}}$ were characterized. Apart from three cases, all cases were mosaic containing at least an additional cell line with 45 chromosomes $(45, \mathrm{X})$. Two of the cases were male (cases m-urY-18 and $\mathrm{m}$-iY-q11.22/1-3), the remaining 15 cases female. The $\mathrm{sSMC}^{\mathrm{T}}$ were derived from the $\mathrm{X}$ chromosome in the majority (12 cases) of the cases tested here. The different shapes of the $\mathrm{SSMC}^{\mathrm{T}}$ are specified in table 1. Ring, centric minute and inverted duplication shape were characterized. An exemplary FISH result is depicted in figure 1. In case m-urY-18 the exact breakpoint in Yq could not be determined due to lack of cytogenetic material. 
Table 1. Results of 17 new cases with an $\mathrm{sSMC}^{\mathrm{T}}$

\begin{tabular}{|c|c|c|c|c|c|c|}
\hline $\begin{array}{l}\text { rX-p11.3 11.4/ } \\
1-1\end{array}$ & 79 & $\begin{array}{l}\mathrm{r}(\mathrm{X})(\mathrm{p} 11.3 \sim 11.4 \mathrm{q} 13.3)[19 \%] / \\
\mathrm{r}(\mathrm{X} ; \mathrm{X})(\mathrm{p} 11.3 \sim 11.4 \mathrm{q} 13.3: \mathrm{p} 11.3 \sim 11.4 \mathrm{q} 13.3)[2 \%]\end{array}$ & n.a. & + & + & + \\
\hline $\begin{array}{l}\text { rX-p11.2 11.3/ } \\
1-1\end{array}$ & 11 & $\begin{array}{l}\mathrm{r}(\mathrm{X})(\mathrm{p} 11.2 \sim \mathrm{p} 11.3 \mathrm{q} 21)[66 \%] / \\
\min (\mathrm{X})(\mathrm{p} 11.2 \sim \mathrm{p} 11.3 \mathrm{q} 21)[23 \%]\end{array}$ & n.a. & n.a. & + & + \\
\hline $\begin{array}{l}\text { rX-p11.2/ } \\
1-1\end{array}$ & 16 & $\mathrm{r}(\mathrm{X})(\mathrm{p} 11.2 \mathrm{q} 13)$ & + & - & + & + \\
\hline $\begin{array}{l}\text { rX-p11.2/ } \\
2-1\end{array}$ & 80 & $\mathrm{r}(\mathrm{X})(\mathrm{p} 11.2 \mathrm{q} 13.1)$ & n.a. & + & + & + \\
\hline $\begin{array}{l}\text { iX-p11.1/ } \\
1-1\end{array}$ & 30 & $\begin{array}{l}\operatorname{idic}(X)(p 11.1 q 12:: q 12 q 11.1)[54 \%] / \\
\text { XX[16\%] }\end{array}$ & + & - & + & + \\
\hline $\min _{2-1} \mathrm{X}-\mathrm{p} 11.2 /$ & 9 & $\begin{array}{l}\min (\mathrm{X})(\mathrm{p} 11.2 \mathrm{q} 12)[18 \%] / \\
\min (\mathrm{X})(: \mathrm{q} 12 \rightarrow \mathrm{p} 11.2:: \mathrm{p} 11.2 \rightarrow \mathrm{q} 12:)[6 \%] / \\
\mathrm{XXX}[5 \%] / \mathrm{XX}[62 \%]\end{array}$ & n.a. & n.a. & n.a. & + \\
\hline $\min _{2-1} \mathrm{X}-\mathrm{p} 11.1 /$ & 60 & $\begin{array}{l}\min (\mathrm{p} 11.1 \mathrm{q} 11:: \mathrm{q} 11 \mathrm{p} 11.1 \text { or } \mathrm{q} 11 \mathrm{p} 11.1:: \mathrm{p} 11.1 \mathrm{q} 11 \text { or : } \\
\mathrm{q} 11 \mathrm{p} 11.1:: \mathrm{q} 11 \mathrm{p} 11.1)\end{array}$ & n.a. & n.a. & + & + \\
\hline $\min _{3-1} \mathrm{X}-\mathrm{p} 11.1 /$ & 46 & $\min (\mathrm{X})(\mathrm{p} 11.1 \mathrm{q} 13.2 \sim 13.3)$ & n.a. & + & - & + \\
\hline $\min _{4-1} \mathrm{X}-\mathrm{p} 11.1 /$ & $\begin{array}{l}32 \\
\text { (amnion) }\end{array}$ & $\begin{array}{l}\operatorname{mar} 1 \mathrm{a}=\min (\mathrm{X})(\mathrm{p} 11.1 \mathrm{q} 11.21:)[9] / \\
\operatorname{mar} 1 \mathrm{~b}=\min (\mathrm{q} 11.21 \mathrm{p} 11.1: \mathrm{p} 11.1 \mathrm{q} 11.21)[4] / \\
\operatorname{mar} 1 \mathrm{c}=\mathrm{r}(\mathrm{X})(\mathrm{q} 11.21 \mathrm{p} 11.1: \mathrm{p} 11.1 \mathrm{q} 11.21:: \mathrm{q} 11.21 \mathrm{p} 11.1:: \\
\mathrm{p} 11.1 \mathrm{q} 11.21)[1] / \\
\operatorname{mar} 2=\min (\mathrm{X})(: \mathrm{p} 11.1 \rightarrow \mathrm{q} 11.1:)[10] \\
\text { complex mosaic: } \operatorname{mar} 1 \mathrm{a}+\operatorname{mar} 2[6] / \\
\operatorname{mar} 1 \mathrm{~b}+\operatorname{mar} 2[3] / \\
\operatorname{mar} 1 \mathrm{c}+\operatorname{mar} 2[1] / \\
\operatorname{mar} 1 \mathrm{a}[3] / \operatorname{mar} 1 \mathrm{~b}[1] / \operatorname{mar} 2[1]\end{array}$ & n.a. & n.a. & n.a. & + \\
\hline $\begin{array}{l}\mathrm{f}-\mathrm{iY}-\mathrm{q} 11.2 / \\
1-18\end{array}$ & $+(\%$ n.a. $)$ & $\operatorname{idic}(\mathrm{Y})(\mathrm{q} 11.2)$ & n.a. & n.a. & n.a. & prenatal \\
\hline $\begin{array}{l}f-\min Y-p 11.1 / \\
1-1\end{array}$ & - & $\min (\mathrm{Y})(: \mathrm{p} 11.1 \rightarrow \mathrm{q} 11.1:)$ & n.a. & n.a. & + & + \\
\hline m-urY-18 & - & $\mathrm{r}(\mathrm{Y})(\mathrm{p} 11.2 \rightarrow \mathrm{q} ?)$ & n.a. & - & + & + \\
\hline $\begin{array}{l}\mathrm{m}-\mathrm{iY}-\mathrm{q} 11.22 / \\
1-3\end{array}$ & 14 & $\operatorname{idic}(\mathrm{Y})(\mathrm{q} 11.22)$ & + & + & + & - \\
\hline
\end{tabular}

n.a. = Not available.

Frequency of 46,X,+mar Cases

$\mathrm{sSMC}^{\mathrm{T}}$ in general are extremely rare findings: approximately 1 sSMC $^{\mathrm{T}} / 100,000$ newborn cases and 7/100,000 prenatal diagnoses are reported. No such cases were detected in 4,269 prenatal diagnoses with ultrasound ab- normalities or 4,562 ICSI cases (table 2). In developmentally and/or mentally retarded patients $\mathrm{SSMC}^{\mathrm{T}}$ were present in $9 / 19,170$ cases $(0.060 \%$ ) (table 3 ) and in patients with fertility problems in $12 / 26,938$ cases $(0.045 \%)$ (table 4). 
Table 2. Twenty studies on consecutively collected prenatal cases are summarized, detecting $\mathrm{sSMC}^{\mathrm{T}}$ in $0.004 \%$ and (mos) $45, \mathrm{X}$ in $0.139 \%$ of cases. Moreover, 19 studies on two pre-selected subpopulations of prenatal diagnostics are listed, detecting only sS$\mathrm{MC}^{\mathrm{T}}$ or Turner karyotypes in ICSI or in ultrasound abnormal prenatal cases.

\begin{tabular}{llll}
\hline $\begin{array}{l}\text { No. of study } \\
\text { [acc. to Liehr } \\
\text { and Weise, 2007] }\end{array}$ & Studied cases & \\
\cline { 2 - 3 } & Overall & $45, \mathrm{X}$ & $45, \mathrm{X} / 46, \mathrm{X},+$ mar \\
\hline
\end{tabular}

Consecutively collected prenatal cases

$\begin{array}{rrrl}1 & 551 & 6 & 0 \\ 3 & 2,500 & 1 & 0 \\ 4 & 2,975 & 11 & 0 \\ 6 & 5,484 & 0 & 0 \\ 7 & 6,515 & 5 & 0 \\ 8 & 5,501 & 9 & 0 \\ 11 & 2,264 & 2 & 0 \\ 13 & 1,687 & 1 & 0 \\ 14 & 7,800 & 19 & 0 \\ 15 & 7,415 & 14 & 2 \\ 16 & 5,165 & 1 & 0 \\ 17 & 1,687 & 10 & 0 \\ 18 & 52,965 & 24 & 0 \\ 22 & 3,000 & 1 & 0 \\ 23 & 15,109 & 5 & 0 \\ 24 & 2,699 & 1 & 0 \\ 26 & 11,436 & 14 & 0 \\ 31 & 15,781 & \text { n.a. } & 5 \\ 35 & 12,454 & 81 & 0 \\ 37 & 2,888 & 4 & 0 \\ \text { Total } & 165,876 & 209(0.139 \%) & 7(0.004 \%)\end{array}$

Only in ultrasound aberrant cases

\begin{tabular}{lrrl}
7 & 875 & 19 & 0 \\
43 & 151 & 7 & 0 \\
44 & 147 & 7 & 0 \\
45 & 288 & 4 & 0 \\
46 & 428 & 4 & 0 \\
47 & 2,143 & 42 & 0 \\
48 & 237 & 8 & 0 \\
Total & 4,269 & $91(2.132 \%)$ & $0(0 \%)$ \\
\hline
\end{tabular}

\begin{tabular}{lrll}
\hline ICSI cases & & & \\
50 & 43 & 0 & 0 \\
51 & 56 & 1 & 0 \\
53 & 71 & 4 & 0 \\
54 & 108 & 0 & 0 \\
55 & 142 & 1 & 0 \\
56 & 146 & 0 & 0 \\
57 & 149 & 0 & 0 \\
58 & 209 & 0 & 0 \\
59 & 1,136 & 3 & 0 \\
60 & 1,586 & 1 & 0 \\
61 & 486 & 0 & 0 \\
62 & 430 & 1 & 0 \\
Total & 4,562 & $11(0.241 \%)$ & $0(0 \%)$ \\
\hline
\end{tabular}

n.a. $=$ Not available.
Table 3. Eight studies on consecutive newborns detecting sSMC and Turner karyotypes. 18 studies each provided data for Turner karyotype and $\mathrm{sSMC}^{\mathrm{T}}$ frequency in (develop)mentally retarded patients.

\begin{tabular}{lrrl}
\hline \multirow{2}{*}{$\begin{array}{l}\text { No. of study } \\
\text { [acc. to Liehr } \\
\text { and Weise, 2007] }\end{array}$} & Total & $45, \mathrm{X}$ & $45, \mathrm{X} / 46, \mathrm{X},+\mathrm{mar}$ \\
\cline { 2 - 4 } & & & \\
\hline Consecutive newborn cases & & \\
63 & 930 & 0 & 0 \\
64 & 2,079 & 0 & 0 \\
65 & 14,835 & 8 & 0 \\
66 & 56,952 & 11 & 0 \\
67 & 3,993 & 0 & 0 \\
69 & 3,665 & 0 & 1 \\
70 & 23,762 & 9 & 0 \\
72 & 1,830 & 0 & 0 \\
Total & 108,046 & $28(0.026 \%)$ & $1(0.001 \%)$ \\
\hline
\end{tabular}

Developmentally and/or mentally retarded patients

$\begin{array}{lrll}21 & 1,443 & \text { n.a. } & 4 \\ 74 & 120 & 0 & 0 \\ 76 & 324 & 0 & 0 \\ 77 & 337 & 6 & 0 \\ 78 & 455 & 1 & 0 \\ 80 & 1,905 & 2 & 1 \\ 81 & 1,586 & 8 & 0 \\ 82 & 972 & 56 & 1 \\ 83 & 470 & 0 & 0 \\ 84 & 4,485 & 6 & 0 \\ 85 & 611 & 0 & 0 \\ 86 & 600 & 2 & 0 \\ 88 & 604 & 2 & 0 \\ 89 & 4,117 & 114 & \mathrm{n} . \mathrm{a} . \\ 90 & 504 & 0 & 0 \\ 92 & 161 & 14 & 1 \\ 93 & 154 & 2 & 2 \\ 94 & 120 & 0 & 0 \\ 95 & 202 & 0 & 0 \\ \text { Total } & 19,170 & 213(1.202 \%) & 9(0.060 \%)\end{array}$

n.a. $=$ Not available.

The frequency of the (mos) 45,X karyotype in the corresponding clinical subgroups was determined (tables $2-4$, fig. 2) as well. The data from Liehr and Weise [2007] concerning the frequency of sSMC was also included in figure 2.

$\mathrm{sSMC}^{\mathrm{T}}$ were detected more frequently in prenatal than in postnatal cases, however, the same observation was made for cases with a karyotype $45, \mathrm{X}$ or an sSMC (fig. 2). This is mainly due to the fact that the postnatal studies are based on consecutive, unselected collectives, while in 
Table 4. In patients with fertility problems Turner karyotypes with or without $\mathrm{sSMC}^{\mathrm{T}}$ were found with frequencies of $0.045 \%$ and $0.969 \%$, respectively. Differences were detected between males and females.

\begin{tabular}{|c|c|c|c|c|c|c|c|c|c|}
\hline \multirow{2}{*}{$\begin{array}{l}\text { No. of study } \\
\text { [acc. to } \\
\text { Liehr and } \\
\text { Weise, 2007] }\end{array}$} & \multicolumn{9}{|c|}{ Studied cases } \\
\hline & Male & Female & Total & Male & Female & Total & Male & Female & Total \\
\hline 52 & 301 & 301 & 602 & 0 & 0 & 0 & 0 & 0 & 0 \\
\hline 54 & 261 & 261 & 522 & 0 & 0 & 0 & 0 & 0 & 0 \\
\hline 77 & 128 & 129 & 57 & 0 & 0 & 0 & 0 & 0 & 0 \\
\hline 98 & 32 & n.a. & 32 & 0 & n.a. & 0 & 0 & n.a. & 0 \\
\hline 99 & 72 & n.a. & 72 & 0 & n.a. & 0 & 0 & n.a. & 0 \\
\hline 100 & 84 & n.a. & 84 & 1 & n.a. & 1 & 0 & n.a. & 0 \\
\hline 101 & 103 & n.a. & 103 & 0 & n.a. & 0 & 3 & n.a. & 3 \\
\hline 103 & 65 & 65 & 130 & 0 & 2 & 2 & 0 & 0 & 0 \\
\hline 104 & 137 & n.a. & 137 & 0 & n.a. & 0 & 0 & n.a. & 0 \\
\hline 110 & 820 & n.a. & 820 & 0 & n.a. & 0 & 0 & n.a. & 0 \\
\hline 111 & 554 & n.a. & 554 & 0 & n.a. & 0 & 1 & n.a. & 1 \\
\hline 112 & 305 & 305 & 610 & 0 & 0 & 0 & 0 & 0 & 0 \\
\hline 113 & 1,007 & n.a. & 1,007 & 2 & n.a. & 2 & 3 & n.a. & 3 \\
\hline 114 & 639 & 639 & 1,278 & 0 & 1 & 1 & 0 & 0 & 0 \\
\hline 115 & 645 & 645 & 1,290 & 1 & 0 & 1 & 0 & 0 & 0 \\
\hline 117 & 781 & 781 & 1,562 & 18 & 4 & 22 & 1 & 0 & 1 \\
\hline 118 & 676 & 624 & 1,300 & 3 & 24 & 27 & 0 & 0 & 0 \\
\hline 119 & 2,196 & 1,012 & 3,208 & 9 & 25 & 34 & 0 & 1 & 1 \\
\hline 120 & 500 & 500 & 1,000 & 0 & 4 & 4 & 0 & 0 & 0 \\
\hline 121 & 432 & 436 & 868 & 1 & 16 & 17 & 0 & 0 & 0 \\
\hline 122 & 1,116 & 1,164 & 2,280 & 3 & 77 & 80 & 0 & 1 & 1 \\
\hline 131 & 496 & n.a. & 496 & 0 & n.a. & 0 & 0 & n.a. & 0 \\
\hline 132 & 88 & n.a. & 88 & 0 & n.a. & 0 & 0 & n.a. & 0 \\
\hline Total & 18,218 & 8,720 & 26,938 & $49(0.269 \%)$ & $212(2.431 \%)$ & $261(0.969 \%)$ & $10(0.055 \%)$ & $2(0.023 \%)$ & $12(0.045 \%)$ \\
\hline
\end{tabular}

n.a.: Not available.

prenatal diagnosis indications like advanced maternal age or ultrasound abnormalities are the reason for amniocentesis. Thus, there is no unselected collective available for the prenatal human population [see as well Liehr and Weise, 2007]. Considering the data for prenatal cases with ultrasound aberrations and those of prenatal cases after ICSI it has to be concluded that $\sim 4,500$ cases each were not sufficient to detect $\mathrm{sSMC}^{\mathrm{T}}$.
Figure 2 clearly shows that in all three groups (mos) $45, \mathrm{X}, \mathrm{sSMC}^{\mathrm{T}}$ and $\mathrm{sSMC}$, the corresponding aberrant karyotype is markedly enhanced in (develop)mentally retarded and infertile patients. For $\mathrm{SSMC}^{\mathrm{T}}$ the detection rate is $\sim 60$-fold higher in (develop)mentally retarded and $\sim 45$-fold enhanced in infertile individuals as compared to the general population. Interestingly, the karyotype (mos) 45,X was predominantly found in female patients

Sex Dev 2007;1:353-362 


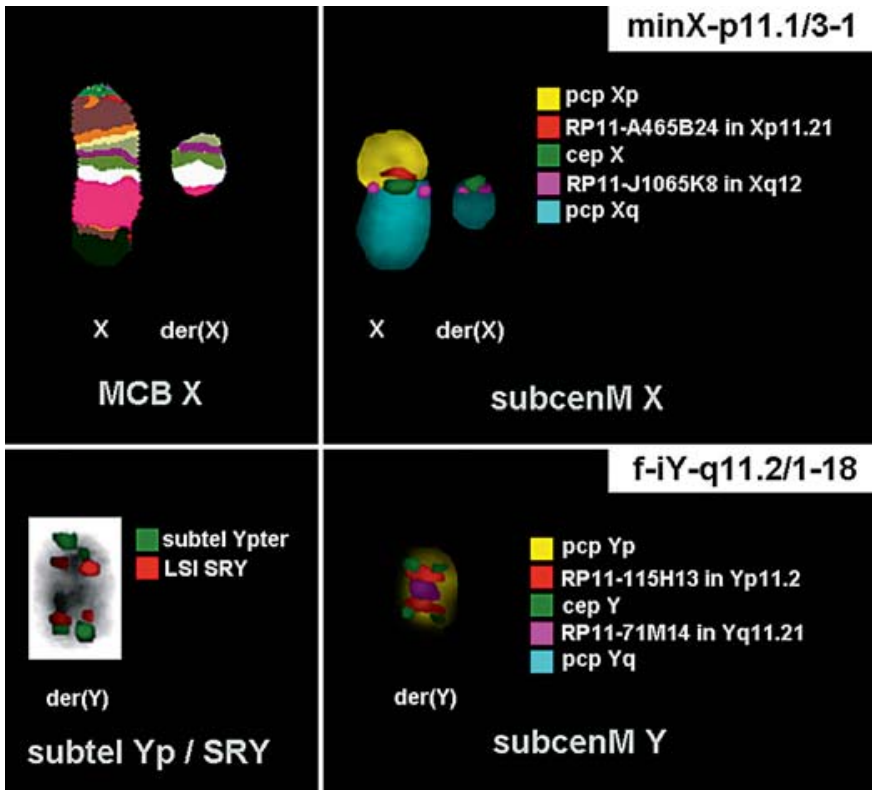

Fig. 1. Different multicolor FISH approaches led to the characterization of the $\mathrm{sSMC}^{\mathrm{T}}$ karyotypes as listed in table 1 . Here two examples of corresponding FISH experiments are shown. In case $\operatorname{minX}$-p11.1/3-1 a $\min (\mathrm{X})(\mathrm{p} 11.1 \mathrm{q} 13.2 \sim 13.3)$ was characterized after application of MCB and subcenM-FISH. Case f-iY-q11.2/1-18: an idic $(\mathrm{Y})(\mathrm{q} 11.2)$ was characterized by subcenM-FISH probe set $\mathrm{Y}$ and two-color FISH using a subtelomeric probe for Ypter and SRY (Abbott/Vysis).

(81\% of patients with fertility problems), while an $\mathrm{sSMC}^{\mathrm{T}}$ was present mainly in males $(83 \%)$.

\section{Origin of $s S M C^{T}$}

The collection of 512 published $\mathrm{sSMC}^{\mathrm{T}}$ cases [Liehr, 2007], allowed to distinguish three different $s S C^{\mathrm{T}}$ groups according to their origin. Most $\mathrm{sSMC}^{\mathrm{T}}$ originate from the $Y$ chromosome $(371 / 512$ cases $=72.6 \%)$. The second largest group is formed by $\mathrm{sSMC}^{\mathrm{T}}$ derived from the $\mathrm{X}$ chromosome $(139 / 512$ cases $=27 \%)$. Surprisingly, there is a third possibility - two $\mathrm{sSMC}^{\mathrm{T}}(0.4 \%)$ that were not derived from one of the gonosomes, but from an autosome are reported in the literature. Wiktor and Van Dyke [2004] report on one case in which the $\mathrm{SSMC}^{\mathrm{T}}$ did not stain with centromeric probes for the $\mathrm{X}$ or $\mathrm{Y}$ chromosome, and Gray et al. [2001] identified an $\mathrm{SSMC}^{\mathrm{T}}$ derived from chromosome 20 . Thus, this third subgroup might be an underestimated entity among $\mathrm{SSMC}^{\mathrm{T}}$ cases.

Other sSMC ${ }^{\mathrm{T}}$ 'special cases' not considered in this review are those with further additional chromosome aberrations. E.g. there are reports on a mos $46, \mathrm{X},+21 / 47, \mathrm{X}$,

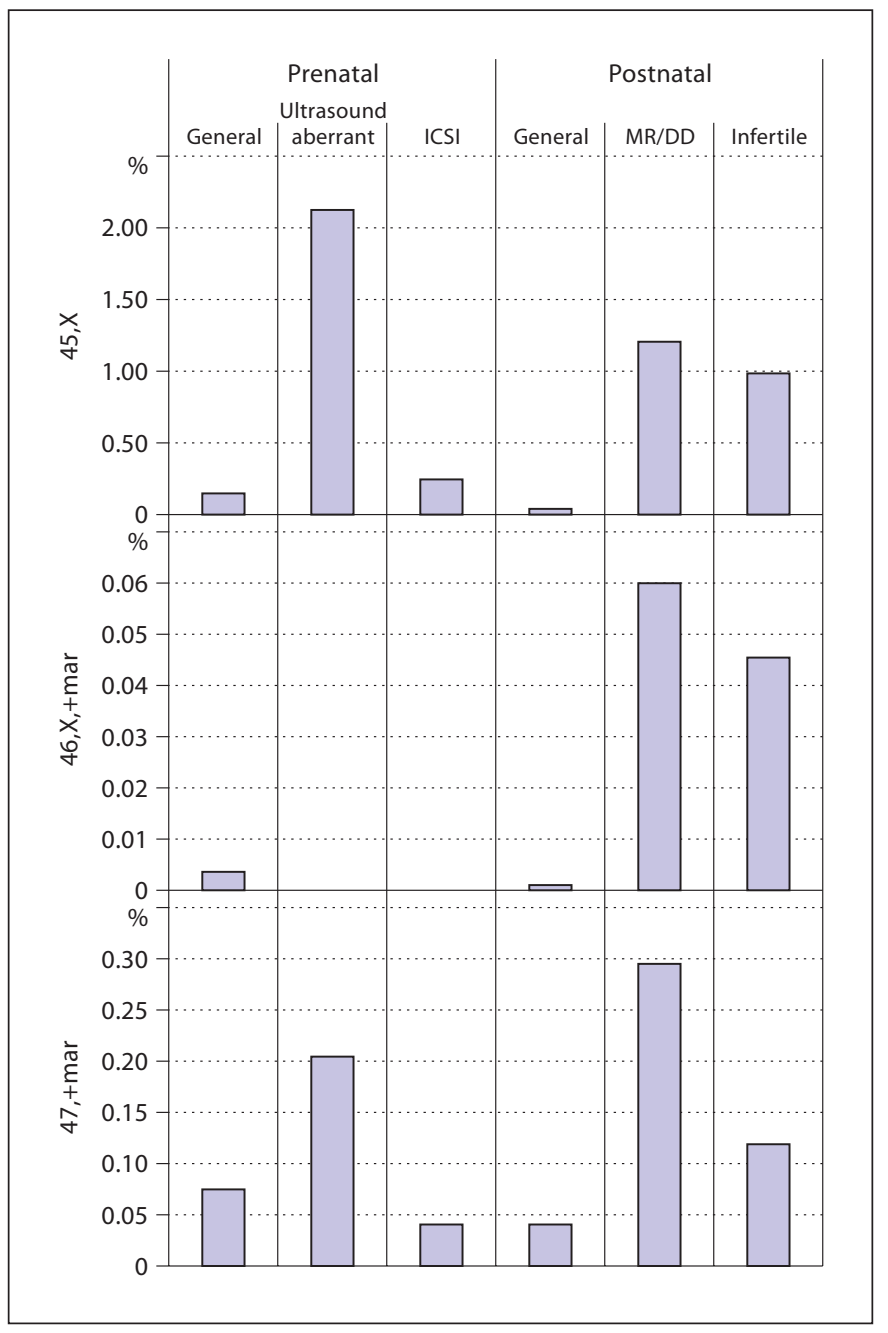

Fig. 2. Frequency of karyotype (mos) $45, \mathrm{X}, 46, \mathrm{X},+\operatorname{mar}\left(=\mathrm{sSMC}^{\mathrm{T}}\right)$ and $47,+$ mar $(=$ sSMC) in pre- and postnatal cases.

$\min (\mathrm{X})(\mathrm{p} 11.1 \mathrm{q} 11.1),+21$ [Li et al., 2000 - case 6], a microdeletion in 15q12 present additionally to a 45,X/46,X,r(Y) [Kurosawa et al., 2004], a karyotype mos 45,dup(X)(p22.2)/ 46,X,idic(Y)(q11) [Stuppia et al., 1996], a case of a 47,XX, $\mathrm{r}(\mathrm{Y})$ pat [Arnedo et al., 2005] and two cases of 46,X,r(X;Y) [Grass et al., 2000; Shago et al., 2002]. Thus, clinical features not necessarily fitting to a 46,X,+mar karyotype strongly indicate further studies in each individual case.

\section{Shapes of $s S M C^{T}$}

sSMC $^{\mathrm{T}}$ can have isodicentric/inverted duplicated (idic), ring (r), or centric minute (min) shapes. The abbreviation 'min' is used according to Crolla [1998] for centric minute sSMC - see also Liehr et al. [2004]. As summa- 

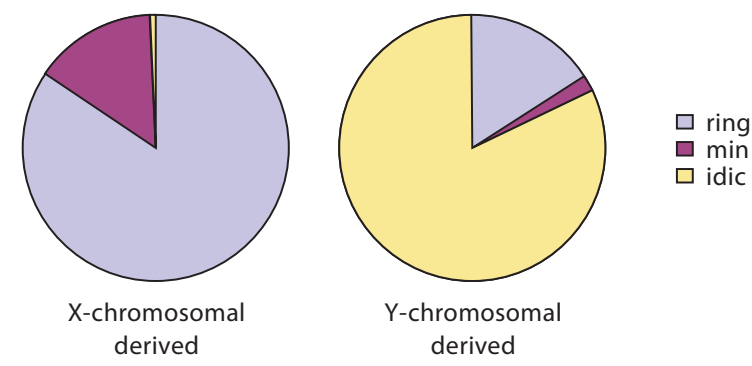

Fig. 3. Distribution of ring-, centric minute (min) and inverted duplication/isodicentric (idic) morphology in $\mathrm{X}$ and $\mathrm{Y}$ chromosome derived $\mathrm{SSMC}^{\mathrm{T}}$ cases.

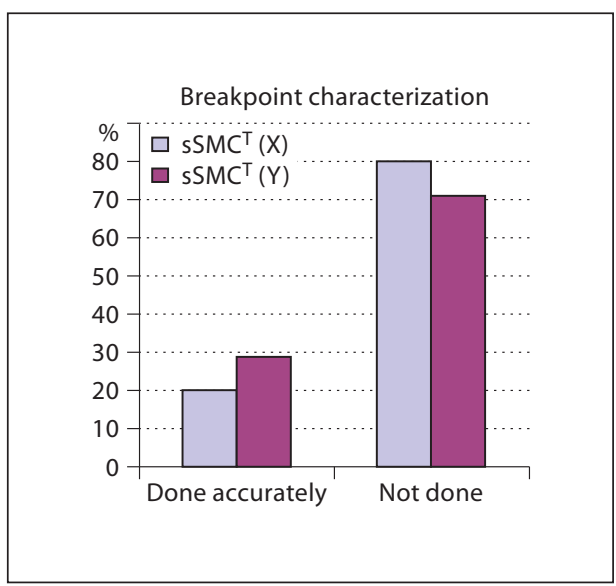

Fig. 4. An accurate breakpoint characterization was done in $20 \%$ and $29 \%$ of $\mathrm{sSMC}^{\mathrm{T}}$ cases derived from the $\mathrm{X}$ and the $\mathrm{Y}$ chromosome, respectively.

rized in figure 3 the shapes of $\mathrm{SSMC}^{\mathrm{T}}$ differ significantly according to their origin. Ring formation is predominant in $\operatorname{sSMC}^{\mathrm{T}}(\mathrm{X})$, while $\mathrm{sSMC}^{\mathrm{T}}(\mathrm{Y})$ are mostly isodicentric/ inverted duplicated chromosomes. The biological basis for this fact is currently still unknown. It is also striking that no direct influence of $\mathrm{sSMC}^{\mathrm{T}}$ shape on the clinical outcome is obvious yet.

\section{Characterization of sSMCT Breakpoints}

In only 28 of $139 \mathrm{sSMC}^{\mathrm{T}}(\mathrm{X})$ and in 107 of $371 \mathrm{sSMC}^{\mathrm{T}}(\mathrm{Y})$ (i.e. in $\sim 25 \%$ of the published cases) the chromosomal breakpoints were characterized on a sound cytogenetic level - i.e. more detailed than Yp1, Yq1, Yp11, Yq11, Xp or

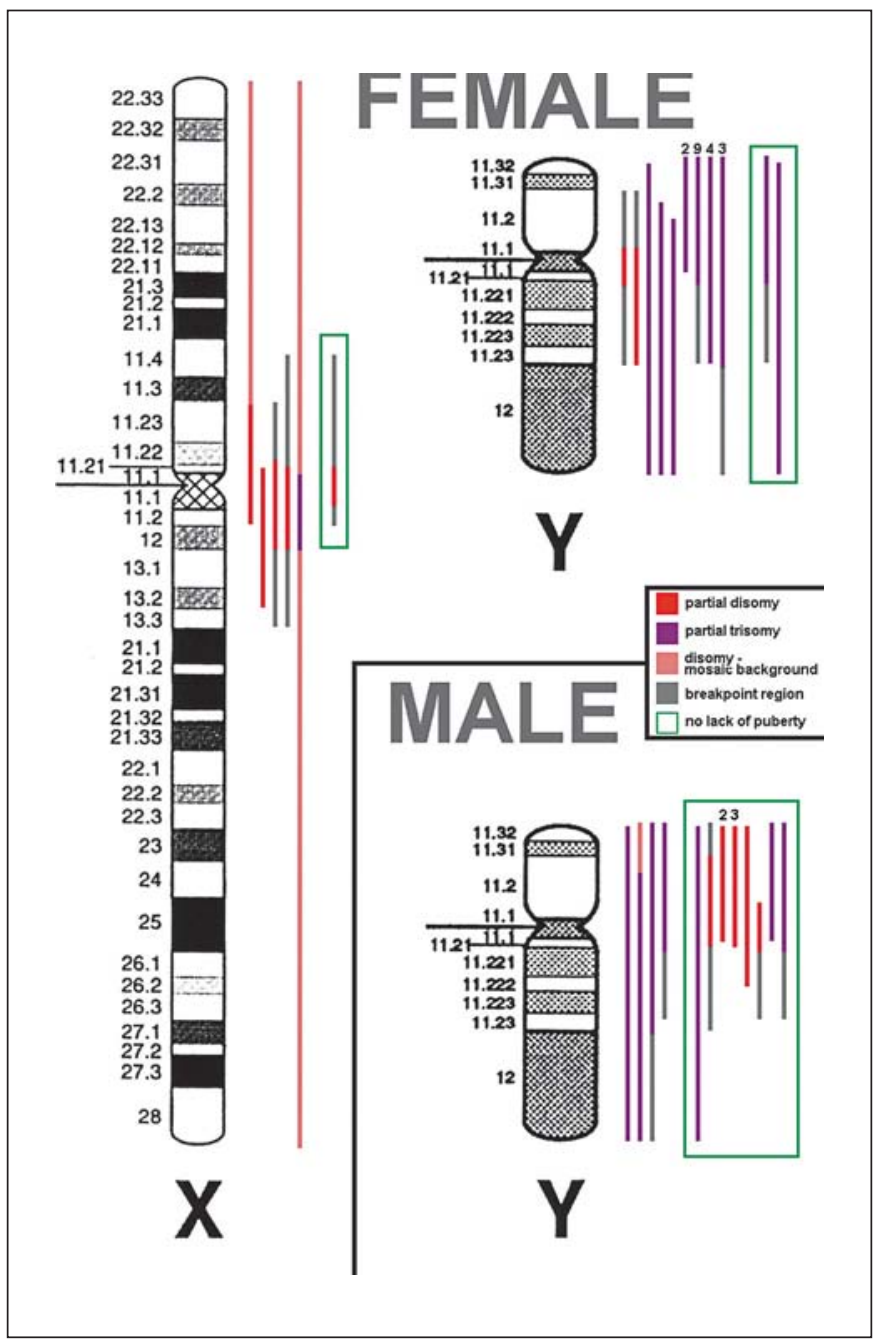

Fig. 5. Imbalances induced by the cytogenetically characterized $\operatorname{sSMC}^{\mathrm{T}}(\mathrm{X})$ and $\operatorname{sSMC}^{\mathrm{T}}(\mathrm{Y})$. Male and female cases are listed separately. Cases with no lack of puberty are marked by green frames. It is obvious, that similar imbalances of the Y chromosome can lead to male or female habitus. Also male development or lack of puberty may be present or absent independently of the chromosomal breakpoints.

Xq [Liehr, 2007] (fig. 4). Here further research may be fruitful. Comprehensively characterized breakpoints in $\mathrm{sSMC}^{\mathrm{T}}$ would contribute to a better understanding of formation and karyotypic evolution of these special marker chromosomes.

\section{Availability of Clinical Data in Cases with an $s S M C^{T}$}

In most published $\mathrm{sSMC}^{\mathrm{T}}$ cases the available clinical data is very limited, especially concerning sexual development. This is mainly due to the fact that $\sim 50 \%$ of such 
Table 5. All sSMC ${ }^{\mathrm{T}}$ patients in whom chromosomal breakpoints were characterized in more detail, with information on gender and pubertal state

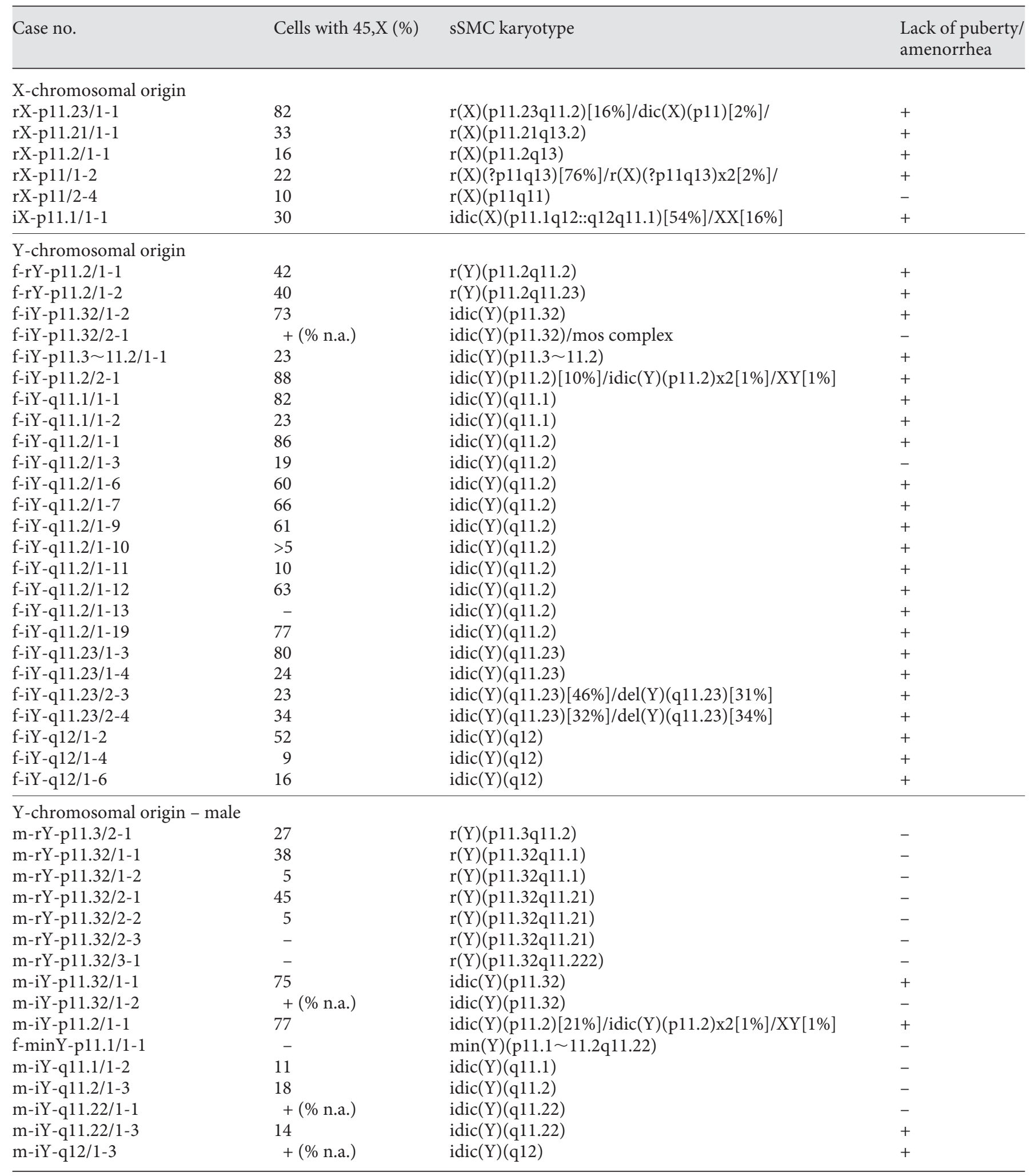

n.a.: Not available. 
cases are detected either prenatally or shortly after birth. Since there are practically no follow-up reports, data on puberty or fertility are not available. Also, in a major part of the literature, authors report only on 'patients with Ullrich-Turner syndrome' without detailing clinical data for individual patients [e.g. Tharapel et al., 1992].

In table 5 we summarize those rare cases with both, cytogenetic characterization of the $\mathrm{sSMC}^{\mathrm{T}}$ and information on lack or presence of puberty and/or amenorrhea. In $5 / 6$ cases with $\mathrm{SSMC}^{\mathrm{T}}(\mathrm{X})$ lack of puberty and/or amenorrhea was reported. The same holds true for $23 / 25$ cases with $\operatorname{sSMC}^{\mathrm{T}}(\mathrm{Y})$ and a more female phenotype. The three cases without problems in sexual development had a karyotype 45,X[10\%]/46,X,r(X)(p11q11)[90\%], mos 45,X/ $46, \mathrm{X}$,idic $(\mathrm{Y})(\mathrm{p} 11.32) /$ other complex aberrations involving gonosomes, and 45,X[19\%]/46,X,idic(Y)(q11.2)[81\%].

In 16 male cases with $\mathrm{sSMC}^{\mathrm{T}}(\mathrm{Y})$ only 4 are reported with delayed or no pubertal development - the karyotypes of these were $45, \mathrm{X}[75 \%] / 46$,X,idic(Y)(p11.32)[25\%], 45,X[77\%]/46,X,idic $(\mathrm{Y})(\mathrm{p} 11.2)[21 \%] / 47, \mathrm{X}, \operatorname{idic}(\mathrm{Y})(\mathrm{p} 11.2) \times$ $2[1 \%] / 46, \mathrm{XY}[1 \%], 45, \mathrm{X}[14 \%] / 46, \mathrm{X}, \mathrm{idic}(\mathrm{Y})(\mathrm{q} 11.22)[86 \%]$, and $\operatorname{mos} 45, \mathrm{X} / 46, \mathrm{X}, \mathrm{idic}(\mathrm{Y})(\mathrm{q} 12)$.

In figure 5 we summarize the imbalances caused by the cytogenetically well characterized $\mathrm{sSMC}^{\mathrm{T}}$ from table 5 . However, practically no correlation was possible concerning size of imbalance induced by $\mathrm{sSMC}^{\mathrm{T}}$ and sexual development. The only obvious fact is, that in presence of an $\mathrm{sSMC}^{\mathrm{T}}(\mathrm{X})$ no male development was observed. Presence of an $\operatorname{sSMC}^{\mathrm{T}}(\mathrm{Y})$ - irrespective of presence or absence of $S R Y$ - could lead to both - male or female de- velopment. According to table 5 a correlation of mosaicism, i.e. size of the clone with an $\operatorname{sSMC}^{\mathrm{T}}(\mathrm{Y})$, and (fe)male development might be suggested, as also reported for monozygotic twins, born as male and female [Fujimoto et al., 1991].

\section{Conclusion}

$\mathrm{sSMC}^{\mathrm{T}}$ are a long known cytogenetic entity. Hundreds of cases have been reported [Liehr, 2007]. Nonetheless, a detailed (molecular) cytogenetic characterization of $\mathrm{sSMC}^{\mathrm{T}}$ was performed only in exceptional cases. This might be due to the fact that a mos $45, \mathrm{X} / 46, \mathrm{X},+$ mar karyotype was regarded as something well known, and thus further studies would not be indicated or straightforward. This review shows that further detailed cytogenetic reports with thorough clinical data are worth to be performed, especially to learn more about formation and effects of an $\mathrm{SSMC}^{\mathrm{T}}$.

\section{Acknowledgements}

Dr. Götz (Wetzlar, Germany), Dr. Junge (Dresden, Germany), Dr. Prager (Dresden, Germany), Dr. Reif (Halle, Germany), Dr. Risch (Liebefeld/Bern, Switzerland), Dr. Sandig (Leipzig, Germany), Dr. Spranger (Bremen, Germany), Dr. Wand (Halle, Germany) and Dr. Wiedemann (Liebefeld/Bern, Switzerland) are gratefully acknowledged for providing patients for the present study, which was supported in parts by the DFG (436 WER 17/5/05, 436 RUS 17/88/06) and the DAAD/British Council (313-ARC-XX-lk).

\section{References}

Alvarez-Nava F, Soto M, Martinez MC, Prieto $\mathrm{M}$, Alvarez Z: FISH and PCR analyses in three patients with $45, \mathrm{X} / 46$, X,idic (Y) karyotype: clinical and pathologic spectrum. Ann Genet 46:443-448 (2003).

-Arnedo N, Nogues C, Bosch M, Templado C: Mitotic and meiotic behaviour of a naturally transmitted ring Y chromosome: reproductive risk evaluation. Hum Reprod 20:462468 (2005).

Bianco B, Lipay MV, Melaragno MI, Guedes AD, Verreschi IT: Detection of hidden Y mosaicism in Turner's syndrome: importance in the prevention of gonadoblastoma. J Pediatr Endocrinol Metab 19:1113-1117 (2006).

- Binder G, Koch A, Wajs E, Ranke MB: Nested polymerase chain reaction study of 53 cases with Turner's syndrome: is cytogenetically undetected Y mosaicism common? J Clin Endocrin Metabol 80:3532-3536 (1995).

Crolla JA: FISH and molecular studies of autoso-
mal supernumerary marker chromosomes
excluding those derived from chromosome
15: II. Review of the literature. Am J Med
Genet 75:367-381 (1998).
Egozcue S, Blanco J, Vendrell JM, Garcia F, Veiga
A, et al: Human male infertility: chromo-
some anomalies, meiotic disorders, abnor-
mal spermatozoa and recurrent abortion.
Hum Reprod Update 6:93-105 (2000).
Fujimoto A, Boelter WD, Sparkes RS, Lin MS, K K
Battersby K: Monozygotic twins of discor-
dant sex both with 45,X/46,X,idic(Y) mosa-
icism. Am J Med Genet 41:239-245 (1991).
Grass FS, Brown CA, Backeljauw PF, Lucas A,
Brasington C, et al: Novel ring chromosome
composed of X- and Y-derived material in a
girl with manifestations of Ullrich-Turner
syndrome. Am J Med Genet 93:343-348
(2000).

rolla JA: FISH and molecular studies of autosomal supernumerary marker chromosomes excluding those derived from chromosome II. Review of the literature. Am J Med A, et al: Human male infert some anomalies, meiotic disorders, abnormal spermatozoa and recurrent abortion.

Gray BA, Bent-Williams A, Wolff DJ, Zori RT: A non-sex chromosome marker in a patient with an atypical Ullrich-Turner phenotype and mosaicism of $46, \mathrm{X}, \mathrm{mar} / 46, \mathrm{XX}$. Clin Genet 60:73-76 (2001).

Hsu LY: Phenotype/karyotype correlations of Y chromosome aneuploidy with emphasis on structural aberrations in postnatally diagnosed cases. Am J Med Genet 53:108-140 (1994).

urosawa K, Harada N, Sosonkina N, Niikawa N, Matsumoto N, Saitoh S: Unmasking 15q12 deletion using microarray-based comparative genomic hybridization in a mentally retarded boy with $\mathrm{r}(\mathrm{Y})$. Am J Med Genet A 130: 322-324 (2004).

Li MM, Howard-Peebles PN, Killos LD, Fallon L, Listgarten E, Stanley WS: Characterization and clinical implications of marker chromosomes identified at prenatal diagnosis. Prenat Diagn 20:138-143 (2000). 
Liehr T: sSMC home page = page on small supernumerary marker chromosomes. http://www.med.uni-jena.de/fish/sSMC/ 00START.htm (2007).

Liehr T, Weise A: Frequency of small supernumerary marker chromosomes in prenatal, newborn, developmentally retarded and infertility diagnostics. Int J Mol Med 19:719731 (2007).

Liehr T, Heller A, Starke H, Rubtsov N, Trifonov $V$, et al: Microdissection based high resolution multicolor banding for all 24 human chromosomes. Int J Mol Med 9:335-359 (2002).

- Liehr T, Claussen U, Starke H: Small supernumerary marker chromosomes (sSMC) in humans. Cytogenet Genome Res 107:55-67 (2004).

Liehr T, Mrasek K, Weise A, Dufke A, Rodriguez $\mathrm{L}$, et al: Small supernumerary marker chromosomes - progress towards a genotypephenotype correlation. Cytogenet Genome Res 112:23-34 (2006).

-Medlej R, Lobaccaro JM, Berta P, Belon C, Leheup B, et al: Screening for Y-derived sex determining gene $S R Y$ in 40 patients with Turner syndrome. J Clin Endocrinol Metab 75:1289-1292 (1992).

-Mittwoch U: Sex determination and sex reversal: genotype, phenotype, dogma and semantics. Hum Genet 89:467-479 (1992).
- Nagafuchi S, Tamura T, Nakahori Y, Takano K, Nishi Y, et al: The majority of the marker chromosomes in Japanese patients with stigmata of Turner syndrome are derived from Y chromosomes. Hum Genet 89:590-592 (1992).

Nishi MY, Domenice S, Medeiros MA, Mendonca BB, Billerbeck AE: Detection of Y-specific sequences in 122 patients with Turner syndrome: nested PCR is not a reliable method. Am J Med Genet 107:299-305 (2002). Erratum in: Am J Med Genet 113:116-117 (2002).

Ogata T, Matsuo N: Turner syndrome and female sex chromosome aberrations: deduction of the principal factors involved in the development of clinical features. Hum Genet 95: 607-629 (1995).

- Park JP, Brothman AR, Butler MG, Cooley LD, Dewald GW, et al: Extensive analysis of mosaicism in a case of Turner syndrome: the experience of 287 cytogenetic laboratories. College of American Pathologists/American College of Medical Genetics Cytogenetics Resource Committee. Arch Pathol Lab Med 123:381-385 (1999).

Ramos ES: Turner syndrome: counseling prior to oocyte donation. Sao Paulo Med J 125: 112-114 (2007).

Sagi L, Zuckerman-Levin N, Gawlik A, Ghizzoni L, Buyukgebiz A, et al: Clinical significance of the parental origin of the $\mathrm{X}$ chromosome in Turner syndrome. J Clin Endocrinol Metab 92:846-852 (2007).
Semerci CN, Satiroglu-Tufan NL, Turan S, Bereket A, Tuysuz B, et al: Detection of Y chromosomal material in patients with a $45, \mathrm{X}$ karyotype by PCR method. Tohoku J Exp Med 211:243-249 (2007).

-Shago M, Sgro M, Barozzino T, Antinucci D, Chakraborty $\mathrm{P}$, et al: An active ring $\mathrm{X}$ and haploinsufficiency of SHOX contribute to short stature, congenital anomalies, and developmental delay in a female. Am J Med Genet 113:279-285 (2002).

Starke H, Nietzel A, Weise A, Heller A, Mrasek $\mathrm{K}$, et al: Small supernumerary marker chromosomes (SMCs): genotype-phenotype correlation and classification. Hum Genet 114: 51-67 (2003)

-Stuppia L, Calabrese G, Franchi PG, Mingarelli $\mathrm{R}$, Morizio E, et al: Molecular studies in three patients with isodicentric Y chromosome. Hum Genet 98:691-695 (1996).

Tharapel SA, Wilroy RS, Keath AM, Rivas ML, Tharapel AT: Identification of the origin of ring/marker chromosomes in patients with Ullrich-Turner syndrome using X and $\mathrm{Y}$ specific alpha satellite DNA probes. Am J Med Genet 42:720-723 (1992).

Wiktor A, Van Dyke DL: FISH analysis helps identify low-level mosaicism in UllrichTurner syndrome patients. Genet Med 6: 132-135 (2004). 